\title{
Research on the Quality Evaluation System of Entrepreneurship Education Based on Efficiency
}

\author{
Xiansheng Liu ${ }^{*}$
}

Xi'an International University, Xi An, 710077, China

\begin{abstract}
Based on the present situation of the domestic development of entrepreneurship education, the research analyzes the necessary conditions for entrepreneurship education courses and teaching, to build the university students' entrepreneurship education quality evaluation system, an empirical analysis on the analytical hierarchy process. By aimed at the design of index system, fully interprets the business of actual results and performance of quality education, to promote the development of entrepreneurship education in colleges and universities. From the perspective of efficiency, to evaluate the quality of the entrepreneurship education indicators divided into two categories: input and output, and uses AHP to determine the weight of each index in the two categories, then applies AHP model to evaluate the efficiency of entrepreneurship education, in order to measure the quality of entrepreneurship education.
\end{abstract}

Keywords: Analytic hierarchy process (AHP), data envelopment analysis (DEA), efficiency, entrepreneurship education, quality evaluation.

\section{INTRODUCTION}

Some western developed countries in the early $1980 \mathrm{~s}$ had entrepreneurial education and training, and obtained great results, become an important way to fuel economic growth. In 2002, China introduced the entrepreneurship education in higher education, and 8 universities such as in Tsinghua, BUAA, have carried on the pilot [1-3]. At present, many universities have set up business education, due to the level of the opening and cultivation objectives and there is a difference system, to avoid the entrepreneurship education resources waste, actively guide entrepreneurship education to the expected development, need to evaluate the quality of the current entrepreneurship education, establish a set of the entrepreneurship education quality evaluation index system. Colleges and universities entrepreneurship education aims to cultivate students' innovation ability, to adapt to the challenges of economic globalization and the knowledge of science and technology era $[4,5]$. It is imparting knowledge at the same time, more emphasis on cultivating students' innovative thinking ability. In the era of knowledge dominate the world, and innovation is the power of a nation's vigorous development [6]. Different development level, different types of countries are called on to build an innovation-oriented country, at the same time the university as an important part of national innovation system, vigorously promote entrepreneurship education, to cultivate a socially responsible and innovative spirit [7-9], entrepreneurial ability of high-quality talent. College students' entrepreneurship education is the important measures to solve the employment problem, the construction of a harmonious society, is to build an innovationoriented country, promoting the economic development of the inevitable requirement, and is to promote students to realize the advantage of the value of life [10-12]. Will venture education into the whole process of talent training, is to update the education idea, reform the personnel training mode, improve the quality of talent cultivation of strategic choice.

\section{OVERVIEW OF ENTREPRENEURSHIP EDUCA- TION QUALITY EVALUATION}

At present, the research on entrepreneurship education quality evaluation of small, can saying is very poor, but from the number of entrepreneurship education quality evaluation quantity are more than 10 papers. This number relative to the quality of education, higher vocational education quality in colleges and universities, college students' comprehensive quality research, dwarf, although only more than 10 , but the thesis research method is changeful, there is a basic direction is from qualitative research to quantitative and qualitative research. The qualitative research articles, such as, Goo, BY in 2003 built the evaluation system of college students' entrepreneurial principles, mainly from five aspects such as subjectivity, practicality, technology, innovation and integrity to build the team. Li, JW put forward their thinking direction and basic principles for performance evaluation of entrepreneurship education in colleges and universities in 2006. Chen, Hk, 2007, entrepreneurship education quality evaluation index system of the building, built a three level indicators index system of total 8 kinds of 40 items. More than the lack of qualitative research mainly reflects in none of these principles and index system of evaluation criteria, it just means to evaluate from the view of these, however, when the actual use of the index weight and grading standards, the indicators don't have a concrete operating measures. To compensate for these shortcomings, combination of qualitative and quantitative research is the research articles appeared in succession, such as Li, GP in 2004 put forward 
by using fuzzy evaluation method to establish the entrepreneurship education quality control system, but it's no further study on the inside of the control system related content. Xie, ZY 2010 in constructing the evaluation index, the index of the set has distinct regional characteristics, combining with the characteristics of entrepreneur background and Jiangsu and Zhejiang area, using the AHP analysis method to the weight of each index for setting, and index evaluation standards are very detailed. The author tried to use the build system makes a simulation evaluation, found that the process of evaluating index system in level three have some indicators, repeat, standard and indicators in part due to too much, caused the index or score, can't find it out, can only use either averages. If using AHP analysis layer 4 indexes of build and weight distribution, the operational level will be greatly enhanced.

Entrepreneurship education quality evaluation is an important content of entrepreneurship education evaluation work, it is not only indispensable value judgment of "quality education", is the condition of "education", "education management," an important test condition. An education quality standard for entrepreneurship education goals have rules and guide effect, is a core element in education quality evaluation. Is the essential purpose of entrepreneurship education evaluation for entrepreneurial education practitioners with the effect of feedback, and gradually improve the quality of entrepreneurship education, as shown in Fig. (1).

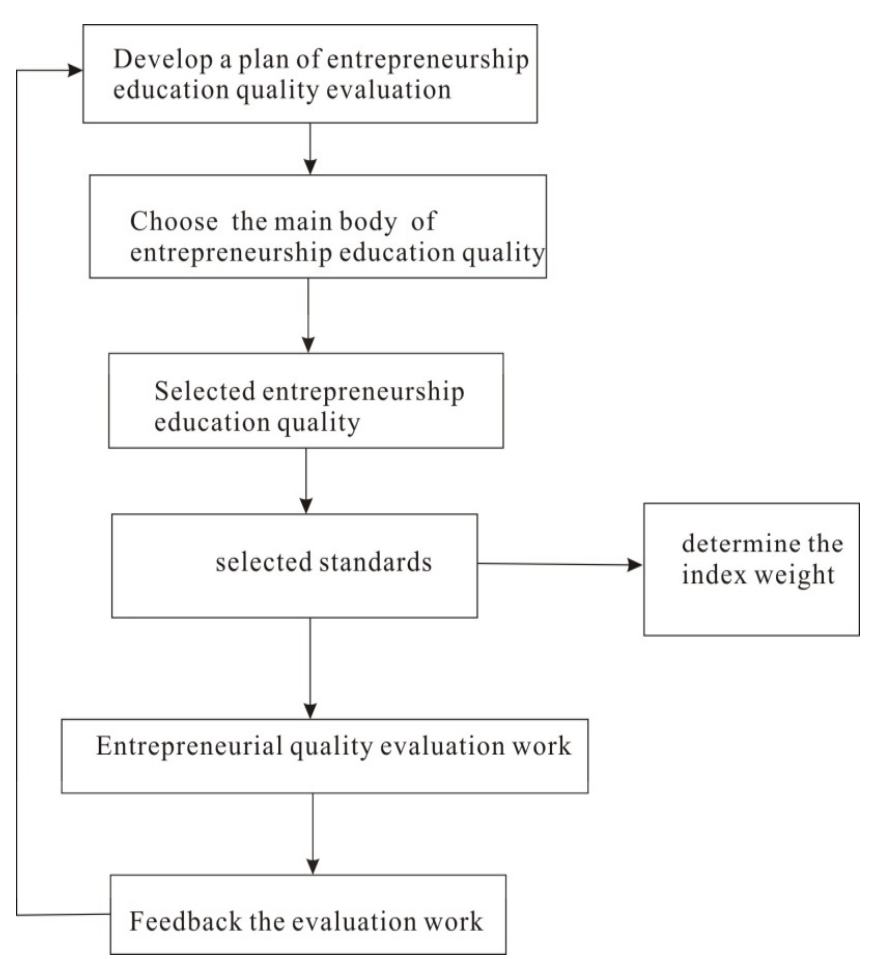

Fig. (1). Entrepreneurship education quality evaluation program diagram.

\section{EFFICIENCY PERSPECTIVE OF ENTREPRE- NEURSHIP EDUCATION QUALITY EVALUATION}

Of literature from the above analysis, can be found that the current for entrepreneurship education quality evaluation has developed to the combination of qualitative and quantitative phase, but these studies all have a common characteristic: the study is in the same plane down. This same plane model dose the study, the results can only be used for horizontal comparison, and comparison with standard cannot be sure, can only make an order. Such as Dong, XH 2009 in his doctoral thesis using the fuzzy mathematics model for a couple of entrepreneurship education in colleges and universities in province has carried on the empirical research, it is concluded that the result is a few schools scores between 84-71 and its conclusion is 84 points, the quality is better, less other below 80 points. However, whether the quality really good score of 84 points, and this is debatable. So, in order to remedy this defect, from the perspective of economics, introduce of the concept of efficiency evaluation.

\subsection{Efficiency}

Efficiency is generally refers to the economic efficiency, is a typical economics term. In the senior Chinese big dictionary "explanation to" efficiency "are as follows: one is per unit time of work completed; the second is the ratio of input and output. And the theoretical circle of economics in the definition of "efficiency" is more professional and in-depth. The "efficiency" in the economics tends to have the following three kinds of parsing: one is the production efficiency, the ratio of input and output per unit of time. Second, allocated efficiency, namely the existing production resources and they provide the contrast between the human to meet; Three is configuration efficiency, is under the condition of invariable in the allocation of resources, because the enterprise internal members degree of efforts to increase or improve the management level and economic benefits. On the surface, economics and the definition of "efficiency" in the reference books differ greatly for the definition of "efficiency", but a further research and economics for the first meaning of "efficiency" analytical, including the relationship between the proportion of input, output and three parts; The second resolution output is the effective output, namely is to satisfy the contrast; The third explanation is that the enterprise operation in the process of its internal conditions influence on the results, the results of this measure, still must use the ratio of input and output of relationship. Therefore, the core part of the connotation is "efficiency" or input, output and proportion relationship. Down the meaning of "efficiency", then "entrepreneurship education and entrepreneurship education of the ratio of effective output" are the meaning of entrepreneurship education efficiency. That is to say, entrepreneurship education into the less, and the effective entrepreneurship education output, the more is said high efficiency; Entrepreneurship education, the more effective entrepreneurship education output is less, is the low efficiency. Therefore, entrepreneurship education quality evaluation indexes can be classified and divided into entrepreneurship education in class and entrepreneurship education output class. So entrepreneurship education quality evaluation is from the perspective of efficiency measure, which can be resolved as the proportion of the relationship between input and output of entrepreneurship education, this proportion relationship to measure entrepreneurship education quality is even more intuitive and obvious. 


\subsection{Methods of the Efficiency}

About efficiency measure method are many, factor analysis, fuzzy mathematics evaluation method, analytic hierarchy process (AHP) and data envelopment analysis, etc. At present, mainly in the efficiency of education research is to use data envelopment analysis (DEA), because the DEA method does not require dimensionless processing of data indicators. However, if the basic model of DEA is used to measure the efficiency, the following question may exist: the number of input and output indicators if DEA model a lot, so most of the evaluation results will show is efficient, it will affect the degree of differentiation of all the evaluation units. DEA in the input and output data are quantitative data, must it quantify the qualitative problem. DEA model is divided into valid and invalid, and the results from these for a further comparison between evaluation units, is difficult to compare, but its super efficiency DEA model can be used to solve.

\subsubsection{AHP Analysis Method}

Analytic hierarchy process (AHP), is the 20th century 70 generation, the United States house of operational research, for some complex and fuzzy problem reasonably use the combination of qualitative and quantitative research, and the problem of complex and fuzzy hierarchical need decision process, and to quantify the various factors after the hierarchical. Because this method especially for those hard to complete quantitative analysis of decision making, and flexible to use, quickly pay attention to and applied in various fields. This article will adopt the method of entrepreneurship education quality evaluation system of each index weight is calculated, the specific steps are as follows:

First, build the evaluation system of the class hierarchy.

Second, construct two comparative judgment matrix, using $1 \sim 9$ scaling method for index after comparing two get a numeric value $\mathrm{K}$ ( $\mathrm{K}$ values for $1 \sim 9$ ) and set up a judgment matrix.

Third, the use of statistical software calculates the weight of each level indicator.

Fourth, to calculate the weight of consistency inspection, if not through the consistency check, you will need to rebuild the judgment matrix.

Fifth, all levels of through the consistency check weight synthesis step by step, determine the weight of each index.

\subsubsection{DEA Analysis Method}

DEA method is put forward in 1978 by Charnes, Cooper and Rhodes, mainly for multiple evaluation units, the method sets up the input and output variables, these variables into effectiveness evaluation. The model expression is as follows:

$$
\left\{\begin{array}{l}
\min \theta \\
\text { s.t. } \sum_{j=1}^{n} \lambda_{j} x_{j} \leq \theta x_{0} \\
\sum_{j=1}^{n} \lambda_{j} y_{j} \geq y_{0}, \lambda_{j} \geq 0, j=1,2 \ldots n
\end{array}\right.
$$

Assume that DMU of $\mathrm{n}$ units will be evaluated, each $\operatorname{DMUj}\{\mathrm{j}=1,2, \ldots, \mathrm{n}\}$ has multiple input and output items, generally input uses $\mathrm{Xj}, \mathrm{Xij} \quad 0$ indicates the $\mathrm{j}$ evaluation unit of DMUj the i input, input with yi, yij shows the output $i$ of DMUj the $\mathrm{j}$ evaluation units. DEA model to calculate the effective evaluation unit efficiency value is 1 , and other evaluation unit efficiency value between 0 and 1 . According to the linear programming, can turn DEA basic model:

On the basis of the basic model to join a condition $\sum \lambda=1$, Get is a model of variable return to scale. But the efficiency of the calculated value by the two models are not more than 1, want to compare multiple evaluation unit cannot further. Andersen and Peters has carried on the revision, to the two models proposed super efficiency DEA model, super efficiency DEA efficiency value can be calculated in more than 1 , and can be conducted to evaluate the efficiency of unit value sorting. Super efficiency DEA model expression is as follows:

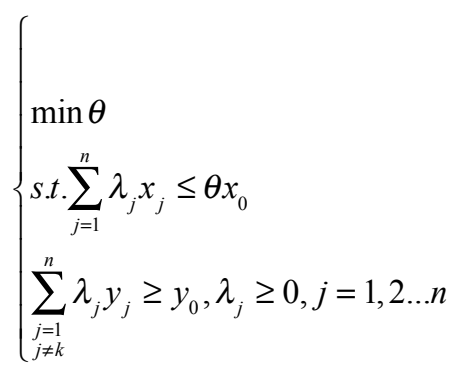

The equation (3) is based on the AHP and super efficiency DEA, for entrepreneurship education efficiency measure, draw lessons from the education efficiency measurement method, choose super efficiency DEA model and AHP method, the combination of using AHP method to determine of entrepreneurship education quality evaluation index weight, and the data as the original input and output of DEA model.

$$
\left\{\begin{array}{l}
\min \theta \\
\text { s.t. } \sum_{\substack{j=1 \\
j \neq k \\
j \neq k}}^{n} \lambda_{j} x_{j} \leq \theta x_{0} \\
\sum_{\substack{j=1 \\
j \neq k}}^{n} \lambda_{j} y_{j} \geq y_{0}, \lambda_{j} \geq 0, j=1,2 \ldots n
\end{array}\right.
$$

\section{THE CONSTRUCTION OF ENTREPRENEURSHIP EDUCATION EFFICIENCY EVALUATION INDEX}

\subsection{The Principle of Index System}

The construction of evaluation index system, need to grasp the characteristics of the object of study and research purposes, using the scientific method, the existence and can explain the several factors of the social phenomena, classified and combined science, finally formed a set of index system "and so, when building entrepreneurship education quality evaluation system needs to insist on the principle of: scientific principle, practical principle, principle of combination of qualitative and quantitative research. 


\subsection{Entrepreneurship Education Quality Evaluation In- dex Selection}

For entrepreneurship education efficiency evaluation index selection, previous research has very important reference, this article will be on the basis of previous studies, and these indicators can be divided into two categories, category as entrepreneurship education output, and a kind of entrepreneurial education investment.

\subsubsection{The Output of Entrepreneurship Education}

It's mainly embodies in the results obtained by the education group, so the education of the students' relevant condition is an important part of evaluation. In addition, to engage in entrepreneurship education teachers, in the process of work to get some representative papers, achievements, etc., promote entrepreneurship education has, should also be as evaluation content. And the influence of entrepreneurship education in the world should also be classified as such.

Entrepreneurship education students is the main object, accept entrepreneurship education students after the training, if he had a pioneering consciousness, whether for entrepreneurship have known some theory, and can seize the opportunity when see the appropriate entrepreneurial opportunities, such as entrepreneurship education quality evaluation, is a very important content. The factors affecting the available set of indicators to measure the following: entrepreneurial intention; Entrepreneurial activity; the theoretical level; Entrepreneurship rate; Students in entrepreneurship education practical evaluation.

Entrepreneurship education teachers in scientific research, such as the curriculum! Teaching methods to explore, entrepreneurship education mechanism research, the business enterprise life cycle management, technical innovation, etc., will be the development of entrepreneurship education has a great role in promoting, at the same time, these results are also constantly improve the quality of entrepreneurship education of the embodiment. The factors affecting the available set of indicators to measure the following: core papers published about entrepreneurship; and the core of the business related papers were cited; Entrepreneurship education achievement adopted by relevant units; Publishing monographs and textbooks.

Entrepreneurship education in the social impact of entrepreneurial atmosphere that can promote the society as a whole, business model, to further promote entrepreneurship education in the importance of the society. Such as Shi Y Z and Ma Y are many students object of worship. The power of this model not only in society, are more successful entrepreneurs to promote their own way. The factors affecting the available set of indicators to measure the following: entrepreneurial activity area of colleges and universities; Entrepreneurial success of alumni's contribution to the Alma mater; The number of enterprises as the entrepreneurship practice base; Entrepreneurship education results in the public opinion support entrepreneurship education output index system of building as shown in Table 1.

\subsubsection{The Input of Entrepreneurship Education}

Mainly embodied in the curriculum setup, such as setup of course system, capable of embodying the of the entrepre-
Table 1. Entrepreneurship education output index system.

\begin{tabular}{|c|c|c|}
\hline 1 & 2 & 3 \\
\hline \multirow{12}{*}{$\begin{array}{l}\text { Entrepreneurship } \\
\text { education output }\end{array}$} & \multirow{5}{*}{ Students } & Entrepreneurial intention \\
\hline & & Entrepreneurial activity \\
\hline & & Theoretical level \\
\hline & & Rate of entrepreneurship \\
\hline & & $\begin{array}{l}\text { Students' evaluation for entrepreneur- } \\
\text { ship education practical }\end{array}$ \\
\hline & \multirow{4}{*}{ Teachers } & $\begin{array}{l}\text { About the core of the business papers } \\
\text { published }\end{array}$ \\
\hline & & $\begin{array}{l}\text { The core of the business related pa- } \\
\text { pers are cited }\end{array}$ \\
\hline & & $\begin{array}{l}\text { Entrepreneurship education are } \\
\text { adopted by relevant units }\end{array}$ \\
\hline & & The publication of the book \\
\hline & \multirow{3}{*}{$\begin{array}{l}\text { Social } \\
\text { effects }\end{array}$} & The area of entrepreneurial dynamism \\
\hline & & $\begin{array}{l}\text { Entrepreneurial success of alumni's } \\
\text { contribution to the Alma mater }\end{array}$ \\
\hline & & $\begin{array}{l}\text { Entrepreneurship education results in } \\
\text { the support of public opinion }\end{array}$ \\
\hline
\end{tabular}

neurship education curriculum richness and related theory, the correlation of at the same time, how to set up good curriculum system play its role, teaching methods, it is very important, and the degree of instructor of experienced, professional title structure also affect the effect of teaching. In addition, the policy support for entrepreneurship is also very important, such as venture fund Settings, school of business support, etc., these are all belong to the entrepreneurship education.

Business itself is a very complex activity, it's about entrepreneurship education teaching requires a high degree of teachers' own quality. Their work experience, professional background is an important factor in its capable of doing the job; as a result, teachers should not only possess profound professional theory, but also has the certain business background. So, in order to ensure the effective development entrepreneurship education and many colleges and universities are increasing in existing entrepreneurship education teachers training and guidance, and actively invite successful entrepreneurs as entrepreneurship education part-time teachers. The factors affecting the available set of indicators to measure the following: entrepreneurial experience teacher ratio; has experienced in training teachers; Entrepreneurs part-time teaching; the teacher title structure.

Around some entrepreneurial education development good countries, such as the United States, Israel, South Korea, you can see they have one thing in common, is from the government to universities institutions, financial institutions, etc., will launch a series of beneficial to create a 
business atmosphere, create entrepreneurial culture, encourage innovation and other measures. Business incubator such as infrastructure, entrepreneurship research institutions for the guidance of the entrepreneurial enterprises, venture capital funds for start-up financing support and other safeguards, which can inspire the students' entrepreneurial passion and entrepreneurial spirit, create a good business atmosphere; promote the development of entrepreneurship education. The factors affecting the available set of indicators to measure the following: startup fund set up; Entrepreneurship preferential policies; Entrepreneurship research institutions; the school support for entrepreneurship. Build the index system of entrepreneurship education in the Table 2.

Table 2. Entrepreneurship education index system construction.

\begin{tabular}{|c|c|c|}
\hline 1 & 2 & 3 \\
\hline \multirow{11}{*}{$\begin{array}{l}\text { Entrepreneurship } \\
\text { education input }\end{array}$} & \multirow{3}{*}{ Course } & Entrepreneurship Settings \\
\hline & & Theory teaching \\
\hline & & Practical teaching \\
\hline & \multirow{4}{*}{ Teachers } & $\begin{array}{c}\text { Teacher ratio have entrepreneurial } \\
\text { experience }\end{array}$ \\
\hline & & $\begin{array}{c}\text { Teacher ratio have training expe- } \\
\text { rience }\end{array}$ \\
\hline & & Entrepreneurs part-time teaching \\
\hline & & Structure of professional title \\
\hline & \multirow{4}{*}{$\begin{array}{l}\text { Environmental } \\
\text { policy }\end{array}$} & Entrepreneurs Foundation \\
\hline & & $\begin{array}{l}\text { Entrepreneurship preferential } \\
\text { policies }\end{array}$ \\
\hline & & $\begin{array}{l}\text { Entrepreneurship research institu- } \\
\text { tions }\end{array}$ \\
\hline & & $\begin{array}{l}\text { The school support for entrepre- } \\
\text { neurship }\end{array}$ \\
\hline
\end{tabular}

\subsection{Matrix and Weight Determination and Inspection}

According to the index system of each index relative important degree, constructs the judgment matrix, and using Mathematic. 5.0 Software finds the solution for the construction of the judgment matrix, obtained the weight coefficient of every index, and the consistency check.

$$
A_{\text {output }}=\left[\begin{array}{lll}
1 & 7 & 6 \\
1 / 7 & 1 & 1 / 3 \\
1 / 6 & 3 & 1
\end{array}\right]
$$

Through software operation obtains $\lambda_{\max }=3.09993$, $\mathrm{CI}=0.049965$ and $\mathrm{CR}=0.086<0.1$, The matrix through the consistency check, entrepreneurship education output corresponding to the three level 2 refers to target weights, respectively $\{0.750407,0.0782482,0.171345\}$.

$$
A_{\text {input }}=\left[\begin{array}{lll}
1 & 3 & 2 \\
1 / 3 & 1 & 1 / 3 \\
1 / 2 & 3 & 1
\end{array}\right]
$$

Through software operation obtains $\lambda_{\max }=3.05362$, $\mathrm{CI}=0.02681$ and $\mathrm{CR}=0.0462<0.1$, The matrix through the consistency check, entrepreneurship education output corresponding to the three level 2 refers to target weights, respectively $\{0.527836,0.139648,0.332516\}$.

$$
A_{\text {student }}=\left[\begin{array}{lllll}
1 & 2 & 3 & 1 / 5 & 7 \\
1 / 2 & 1 & 2 & 1 / 6 & 6 \\
1 / 3 & 1 / 2 & 1 & 1 / 4 & 5 \\
5 & 6 & 4 & 1 & 9 \\
1 / 7 & 1 / 6 & 1 / 5 & 1 / 9 & 1
\end{array}\right]
$$

Through software operation obtains $\lambda_{\max }=5.36495$, $\mathrm{CI}=0.0912375$ and $\mathrm{CR}=0.0815<0.1$, The matrix through the consistency check, entrepreneurship education output corresponding to the weights, respectively $\{0.196948,0.128025$, $0.0952330 .550093,0.0297004\}$.

$$
A_{\text {teacher }}=\left[\begin{array}{llll}
1 & 1 / 2 & 2 & 1 / 2 \\
2 & 1 & 3 & 1 \\
1 / 2 & 1 / 3 & 1 & 1 / 3 \\
2 & 1 & 3 & 1
\end{array}\right]
$$

Through software operation obtains $\lambda_{\max }=4.01036$, $\mathrm{CI}=0.00345$ and $\mathrm{CR}=0.00384<0.1$, The matrix through the consistency check, entrepreneurship education output corresponding to the weights, respectively $\{0.18906,0.350913$, $0.109114,0.350913\}$.

$$
A_{\text {social effect }}=\left[\begin{array}{ccccc}
1 & 2 & 3 & 4 \\
1 / 2 & 1 & 2 & 3 \\
1 / 3 & 1 / 2 & 1 & 2 \\
1 / 4 & 1 / 3 & 1 / 2 & 1
\end{array}\right]
$$

Through software operation obtains $\lambda_{\max }=4.03098$, $\mathrm{CI}=0.01035$ and $\mathrm{CR}=0.0115<0.1$, The matrix through the consistency check, entrepreneurship education output corresponding to the weights, respectively $\{0.467296,0.277181$, $0.160088,0.095435\}$.

$$
A_{\text {class }}=\left[\begin{array}{lll}
1 & 1 & 1 / 2 \\
1 & 1 & 1 / 2 \\
2 & 2 & 1
\end{array}\right]
$$

Through software operation obtains $\lambda_{\max }=3.0000, \mathrm{CI}=0$ and $\mathrm{CR}=0<0.1$, The matrix through the consistency check, entrepreneurship education output corresponding to the weights, respectively $\{0.25,0.25,0.5\}$.

From the above all, through the consistency check of judgment matrix calculation results, can get the weight of each index is as follows:

$$
\begin{aligned}
& \left.W_{\text {output }}=0.750407,0.0782482,0.171345\right\} \\
& W_{\text {input }}=\{0.527836,0.139648,0.332516\}
\end{aligned}
$$




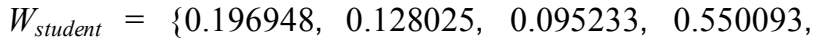
$0.0297004\}$

$W_{\text {teacher }}=\{0.18906,0.350913,0.109114,0.350913\}$.

$W_{\text {social effect }}=\{0.467296,0.277181,0.160088,0.095435\}$.

$W_{\text {class }}=\{0.25,0.25,0.5\}$.

\section{CONCLUSION}

In this paper, the research on entrepreneurship education quality evaluation is established on the basis of previous studies, from the Angle of economics, introducing the efficiency study of entrepreneurial education quality evaluation, the evaluation index can be divided into output and input indicators, using the AHP analysis method, the weights of each index was calculated, and the calculation model of DEA efficiency of input and output items. Insufficient place is not collect data on the model for empirical research, and it is also in this paper, continue to work hard in the direction of the later. All the people want to put forward different opinions about this, and are devoted to the study of entrepreneurship education quality evaluation method.

Entrepreneurship education as entrepreneurial innovation personnel training important way, received extensive attention from all walks of life. Build a kind of entrepreneurial education quality evaluation model, the purpose is to improve the innovation entrepreneurship education quality, through the implementation of entrepreneurship education quality evaluation system to feedback effect, to a certain extent will provide entrepreneurship education development direction and standards. This article only entrepreneurial education class teaching, extracurricular practice and entrepreneurship education environment about entrepreneurship education performance evaluation indexes are put forward. In this paper, although with some positive and beneficial exploration and attempt, but there are still many deep-seated problems remain to be solved. For entrepreneurship education evaluation function, to take into account the result evaluation and process evaluation, evaluation results should be in accordance with the process of the specific work of evaluation objects, to improve the specific working process of the evaluation object. In terms of entrepreneurship education evaluation tools and means, to consider the combination of qualitative and quantitative, scientific method and humanistic method, the combination of both to embody entrepreneurship education evaluation scientific and rational appeal, and performance evaluation of education human caring. Hope that through the study of entrepreneurship education quality evaluation system, to promote the development of innovative entrepreneurship education in colleges and universities.

\section{CONFLICT OF INTEREST}

The author confirms that this article content has no conflict of interest.

\section{ACKNOWLEDGEMENTS}

Declared none.

\section{REFERENCES}

[1] S. Shane, and S. Venkataraman, "The promise of entrepreneurship as a field of research," Academy of Management Review, vol. 25, no. 1, pp. 217-226, 2000.

[2] Z. J. Acs, P. Braunerhjelm, D. B. Audretsch, and B. Carlsson, "The knowledge spillover theory of entrepreneurship," Small Business Economics, vol. 32, no. 1, pp. 15-30, 2009.

[3] L. Papayannakis, I. Kastelli, D. Damigos, and G. Mavrotas, "Fostering entrepreneurship education in engineering curricula in Greece. Experience and challenges for a Technical University," European Journal of Engineering Education, vol. 33, no. 2, pp. 199-210, 2008.

[4] L.F. Edelman, T.S. Manolova, and C.G. Brush, "Entrepreneurship education: Correspondence between practices of nascent entrepreneurs and textbook prescriptions for success," Academy of Management Learning \& Education, vol. 7, no. 1, pp. 56-70, 2008.

[5] S. Dhliwayo, "Experiential learning in entrepreneurship education: A prospective model for South African tertiary institutions," $E d u$ cation + Training, vol. 50, no. 4, pp. 329-340, 2008.

[6] J. Youtie, and P. Shapira, "Building an innovation hub: A case study of the transformation of university roles in regional technological and economic development," Research Policy, vol. 37, no. 8, pp. 1188-1204, 2008.

[7] H.Y. Wu, Y.K. Lin, and C.H. Chang, "Performance evaluation of extension education centers in universities based on the balanced scorecard," Evaluation and Program Planning, vol. 34, no. 1, pp. 37-50, 2011.

[8] R. Deem, K.H. Mok, and L. Lucas, "Transforming higher education in whose image? Exploring the concept of the 'world-class' university in Europe and Asia," Higher Education Policy, vol. 21, no. 1, pp. 83-97, 2008.

[9] W.H. Kong, and T.T. Fu, "Assessing the performance of business colleges in Taiwan using data envelopment analysis and student based value-added performance indicators," Omega, vol. 40, no. 5, pp. 541-549, 2012.

[10] T. Yunting, "The study on human resource management performance evaluation based on data envelopment analysis and analytic hierarchy process, " JDCTA: International Journal of Digital Content Technology and its Applications, vol. 6, no. 14, pp. 256-265, 2012.

[11] C.G. Şen, and G. Çınar, "Evaluation and pre-allocation of operators with multiple skills: A combined fuzzy AHP and max-min approach," Expert Systems with Applications, vol. 37, no. 3, pp. 20432053, 2010.

[12] S.J. Joo, J.G. H. Messer, and R. Bradshaw, "The performance evaluation of existing suppliers using data envelopment analysis," International Journal of Services and Operations Management, vol. 5, no. 4, pp. 429-443, 2009.

Received: June 10, 2015

Revised: July 29, 2015

Accepted: August 15, 2015

(C) Xiansheng Liu; Licensee Bentham Open.

This is an open access article licensed under the terms of the (https://creativecommons.org/licenses/by/4.0/legalcode), which permits unrestricted, noncommercial use, distribution and reproduction in any medium, provided the work is properly cited. 